\title{
Population Variability of Almond-Leaved Willow (Salix triandra L.) Based on the Leaf Morphometry: Isolation by Distance and Environment Explain Phenotypic Diversity
}

\author{
Katarina Tumpa ${ }^{1}$, Zlatko Šatović ${ }^{2,3} \mathbb{D}$, Antonio Vidakovićc ${ }^{1}$, Marilena Idžojtić ${ }^{1}$, Rudolf Stipetić ${ }^{1}$ \\ and Igor Poljak $1, *$ (D) \\ 1 Institute of Forest Genetics, Dendrology and Botany, Faculty of Forestry and Wood Technology, \\ University of Zagreb, Svetošimunska Cesta 23, HR-10000 Zagreb, Croatia; ktumpa@sumfak.hr (K.T.); \\ avidakovi@sumfak.hr (A.V.); midzojtic@sumfak.hr (M.I.); rstipetic@sumfak.hr (R.S.) \\ 2 Department for Seed Science and Technology, Faculty of Agriculture, University of Zagreb, Svetošimunska \\ Cesta 25, HR-10000 Zagreb, Croatia; zsatovic@agr.hr \\ 3 Centre of Excellence for Biodiversity and Molecular Plant Breeding, Svetošimunska Cesta 25, \\ HR-10000 Zagreb, Croatia \\ * Correspondence: ipoljak@sumfak.hr; Tel.: +385-1-235-2547
}

\section{check for}

updates

Citation: Tumpa, K.; Šatović, Z.; Vidaković, A.; Idžojtić, M.; Stipetić, R.; Poljak, I. Population Variability of Almond-Leaved Willow (Salix triandra L.) Based on the Leaf Morphometry: Isolation by Distance and Environment Explain Phenotypic Diversity. Forests 2022, 13, 420. https://doi.org/10.3390/f13030420

Academic Editors: Jozef Šibík and Flurin Babst

Received: 7 January 2022

Accepted: 28 February 2022

Published: 7 March 2022

Publisher's Note: MDPI stays neutral with regard to jurisdictional claims in published maps and institutional affiliations.

Copyright: (C) 2022 by the authors. Licensee MDPI, Basel, Switzerland. This article is an open access article distributed under the terms and conditions of the Creative Commons Attribution (CC BY) license (https:// creativecommons.org/licenses/by/ $4.0 /)$.

\begin{abstract}
Almond-leaved willow (Salix triandra L., Salicaceae) is a dioecious shrub, rarely a small tree that grows under various environmental conditions. We examined the population structure of 12 populations of almond-leaved willow using nine leaf morphological traits and specific leaf area. Populations were selected from a range of habitats, from continental to the sub-Mediterranean zone, to examine the influence of environmental conditions (climate and altitude) and geographic distance on leaf variability. Significant differences were confirmed among all populations for all traits, with significant correlations between geographic location of populations and morphological traits, and between environmental conditions and morphological traits. Large-leaved populations were found in continental and sub-Mediterranean climates, while small-leaved populations were found in higher elevations and smaller karstic rivers. In addition, populations from floodplains showed greater variability than populations from the karstic habitats, indicating a positive influence of lowland habitats and possible underlying differences in gene pool size. In conclusion, we found that environmental conditions and geographical distances in addition to genetic drift, are the main influences on the variability in almond-leaved willow, with the species showing a high level of plasticity and adaptation to local environmental conditions.
\end{abstract}

Keywords: population diversity; population structure; morphometric analysis; phenotypic variability; isolation by distance; isolation by environment

\section{Introduction}

Leaves are essential organs for photosynthesis and carbon assimilation [1], making their morphological attributes, particularly leaf shape and size, crucial to survival and a plant's adaptation to various climatic challenges [2,3]. As a result, leaves are highly variable among taxa, as well as within each species and even each individual [3-5]. While the variability is most often related to functions of photosynthesis [2,6,7] and drought response [8-10], leaves have been shown to display variability as a result of numerous climatic influences, including temperature [11-13], precipitation [14-16] and light conditions [17-20]. Additionally, the influence of latitude [21,22] and altitude gradient [3] on variations in leaf morphology has been proven. The underlying mechanisms of adaptation are both anatomical and physiological. The structural tissues of leaves, the epidermis, with stomata, mesophyll and vascular tissues, can vary significantly in thickness and shape $[23,24]$. On the other hand, plant hormones and sensitivity to certain hormone concentrations will influence variable morphological responses $[25,26]$. 
High levels of variability, noticeable among different genera as well as within individual species, make leaf morphometric traits valuable in research on population variability [27]. Intraspecific variability, particularly on the population level, might offer beneficial responses to the conditions in the environment, i.e., enable the population to survive [28]. In recent studies, leaf morphometric traits have been used to analyse adaptability of tree species to certain habitats and their specific environmental conditions [29-31]. Increased knowledge on the responses of certain population to variability of the environmental conditions can ease management of such populations, possibly aiding conservation of the endangered genera as well [32]. This is particularly important for riparian species, which live in highly diverse environments, where phenotypic plasticity and adaptation are the keys to adapting to ever-changing conditions [33]. One such genus is Salix L., the willows. Willows are shade-intolerant colonisers and true pioneer species, with a rapid growth rate and tendency to vegetative propagation. Furthermore, some species have proven to be morphologically very variable, with pronounced phenotypic responses to environmental factors [34-36], such as S. alba L., a common short-rotation forest species, and S. viminalis L., used in remediation efforts [37]. In addition, studies on high-yielding willow genotypes revealed the effect of environment to have greater influence on biomass allocation than the genetic background [38], as well as the influence of specific leaf surface structure on the frost tolerance of the clones [39].

Morphological studies have also been conducted on economically insignificant but ecologically relevant species, such as S. reticulata L. [40] and S. herbacea L. [41], with both species demonstrating a correlation between leaf morphometric traits and the climatic conditions. Similar results were reported for the closely related genus Populus L., the poplars. In an earlier research, black poplar ( $P$. nigra L.) had demonstrated significant phenotypic plasticity of the leaves, providing the species with response to environmental variations [42]. Furthermore, the genetic analysis of P. szechuanica var. tibetica C.K. Schneid. ascertained that certain genes were exclusively expressed in lower altitudes, thus revealing the influence of the environment on the phenotypic expression [43].

A prime example of ecologically significant willow species is the almond-leaved willow (S. triandra L.). Native to Eurasia [44], it grows as a tall shrub, rarely a small tree. The defining feature of the species are almond-shaped leaves with parallel edges, explaining the synonymous scientific name, S. amygdalina L. (from Greek amýgdalon, almond). An important distinctive feature is kidney- or half-heart-shaped stipules, which are permanent and most developed on the top of this year's shoots and on the suckerings [45]. As with other Salix species, almond-leaved willow is a dioecious with unisexual flowers and is pollinated by insects, with seed dispersal aided by water and wind [46]. Another identifying feature is the male flowers, which are distinguished by having three non-coherent stamens each, giving the species its name (from Latin triandra, three stamens). Growing in a wide variety of habitats, on a wide range of soil types and in various altitudes, almond-leaved willow is empirically adaptable, although previous research to support the observed population variability is unknown to us. To this date, this species has been a part of a research into Salix germplasm [47] and some research into leaf anatomy [48,49] and sprout regeneration [50] has been conducted. Most recently, the pollen grain morphology has been analysed and the species has been separated from the other species within the subgenus Salix, but remained morphologically similar to numerous species from subgenera Chamaetria and Vetrix [51]. Furthermore, although previously divided into numerous subtaxa, the species is now considered unified, with subtaxa genetically classified as synonyms [47] and the analysis of the leaf's wax layer additionally confirmed these various taxa as a single, unambiguous species [48].

In this study, the phenotypic diversity of almond-leaved willow populations was examined. Plant material, in the form of leaves, was collected from 12 populations growing in diverse climatic conditions. Various statistical methods were employed to analyse leaf morphology variability and test correlations. The hypotheses we tested in this research are as follows: (1) the leaf morphometric traits are positively influenced by favorable 
environmental conditions; (2) leaf traits are correlated with both geographic location and environmental conditions; (3) intra- and inter-population variability are demonstrated by variability of leaf phenotypic traits; and (4) population structure of almond-leaved willow is under the influence of neutral and adaptive evolutionary processes.

\section{Materials and Methods}

\subsection{Plant Material}

Twelve natural populations of almond-leaved willow were selected for the research (Figure 1, Table S1). The habitat conditions varied greatly, with altitudes from 19 to $352 \mathrm{~m}$.a.s.l. and annual precipitation from $723 \mathrm{~mm}$ to $1420 \mathrm{~mm}$. Four populations were located in the floodplains of relatively large rivers, growing on alluvial, well-saturated soils. Remaining populations were located in the higher altitudes, with variable distances from the water's edge and mostly along smaller karstic rivers and rivulets. In each population, five to seven almond-leaved willow shrubs were selected for morphometric analysis. Sampling was conducted during the vegetation period of 2021, after the leaves were fully developed. From each shrub, 20 shoots (Figure 2A), on the external part of the crown and well-lit, were cut and placed in Ziploc plastic bags. Bags were kept in portable freezer containers to additionally prevent them from drying up and deforming. Once collected, samples were taken to the laboratory, and pressed between newspapers and herbarised until the morphometric analysis was conducted.

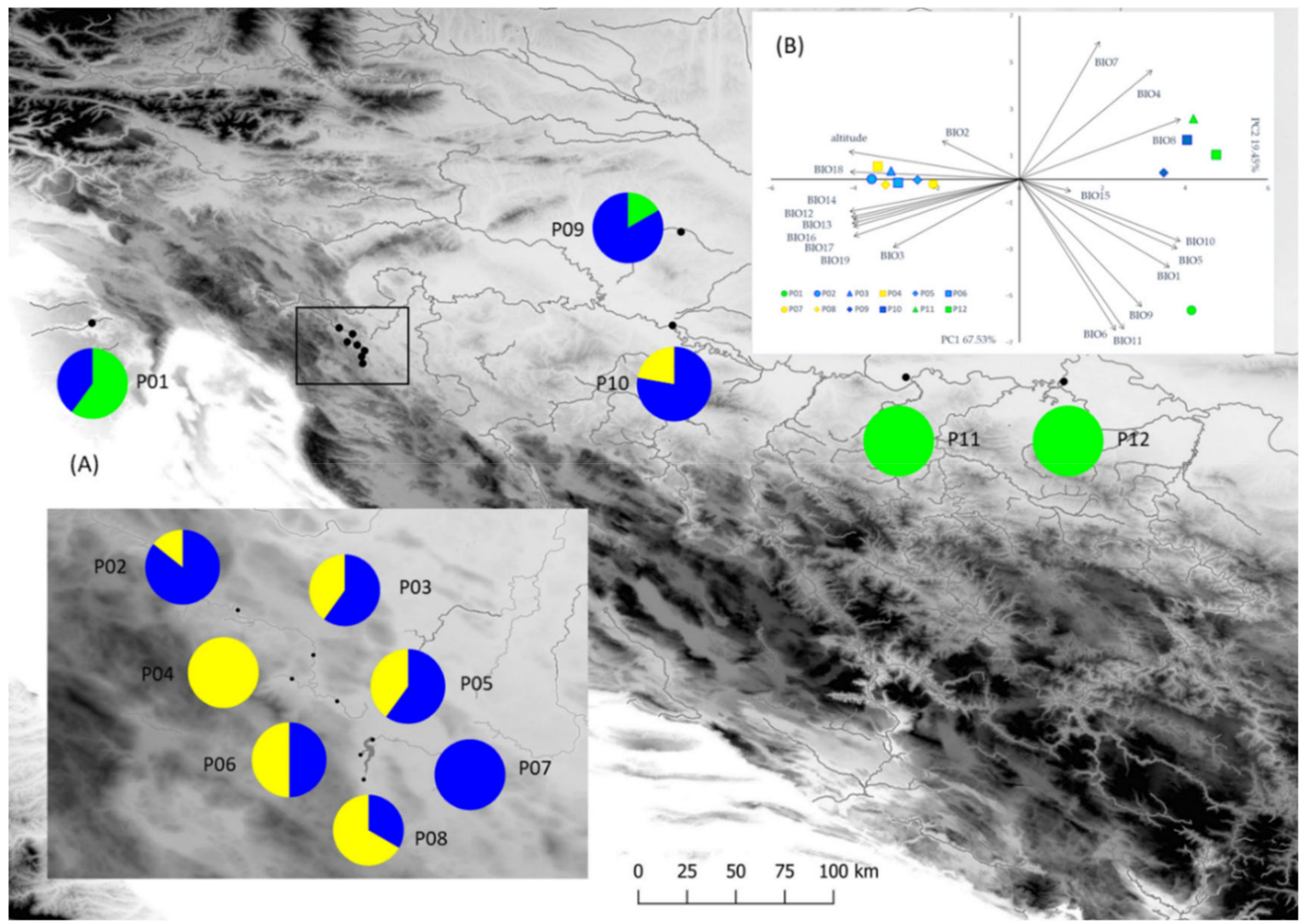

Figure 1. Locations of the 12 sampled Salix triandra populations and the results of the multivariate statistical methods based on nine morphological leaf traits. (A) Geographical distribution of three groups of populations detected from K-means clustering method (the proportions of the membership of each population in each of the defined clusters are colour-coded: cluster A-green, cluster Bblue; cluster C-yellow). (B) Biplot of the principal component (PC) analysis based on altitude and 19 bioclimatic variables. Populations: P01-Mirna; P02-Gomirje; P03—Perić most; P04—Vitunj; P05-Dobra mlin; P06-Zagorska Mrežnica north; P07—Sabljaci; P08—Zagorska Mrežnica south; P09—Lonjsko polje; P10—Narta; P11-Jelas polje; P12-Županja. 

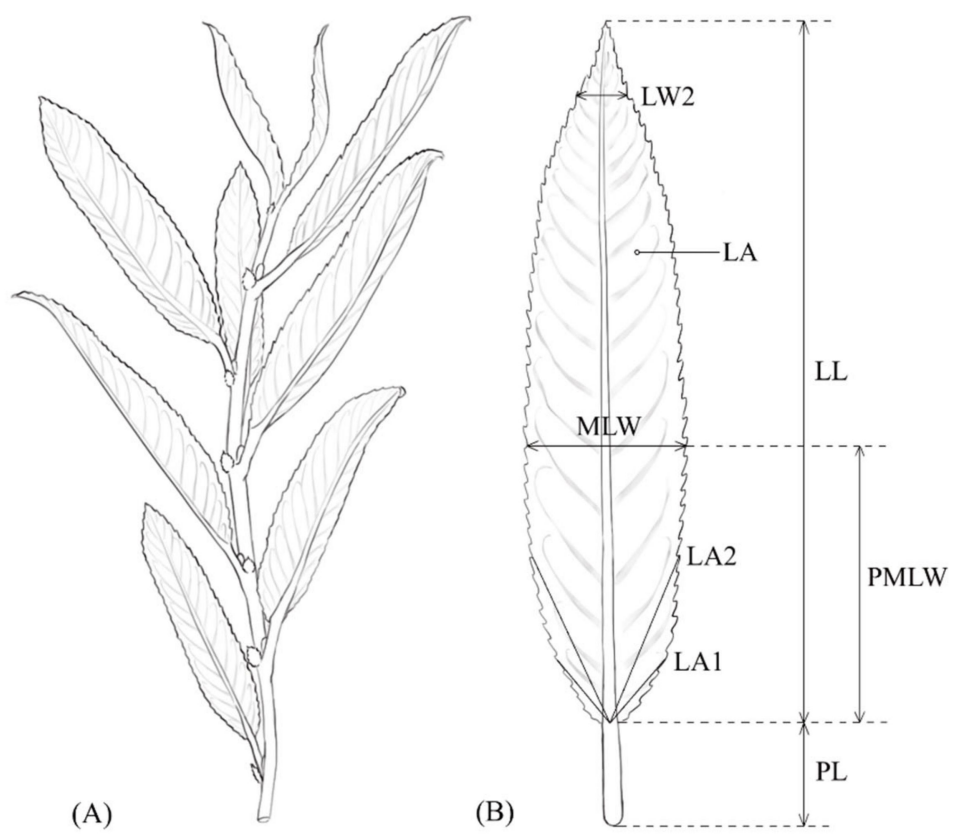

Figure 2. (A) Visual representation of shoots selected for sampling of the leaves. (B) Visual representation of sampled leaf and measured morphometric traits: LA-leaf area; LL-leaf length; MLW—maximum leaf width; PMLW—-leaf length, measured from the leaf base to the point of maximum leaf width; LW2 - leaf blade width at 90\% of leaf blade length; PL-petiole length; LA1—angle closed by the main leaf vein and the line defined by the leaf blade base and a point on the leaf margin, at $10 \%$ of leaf blade length; LA2 - angle closed by the main leaf vein and the line defined by the leaf blade base and a point on the leaf margin, at $25 \%$ of leaf blade length.

\subsection{Environmental Data}

Data on climatic conditions in the area of the studied populations were obtained from the WorldClim2 database with a spatial resolution close to a square kilometre [52]. All 19 bioclimatic variables were included in the study; (Table S1): BIO1 (Annual Mean Temperature); BIO2 (Mean Diurnal Range (Mean of monthly (max temp - min temp)); BIO3 (Isothermality (BIO2/BIO7) $(\times 100)$ ); BIO4 (Temperature Seasonality (standard deviation $\times 100)$ ); BIO5 (Max Temperature of Warmest Month); BIO6 (Min Temperature of Coldest Month); BIO7 (Temperature Annual Range (BIO5-BIO6)); BIO8 (Mean Temperature of Wettest Quarter); BIO9 (Mean Temperature of Driest Quarter); BIO10 (Mean Temperature of Warmest Quarter); BIO11 (Mean Temperature of Coldest Quarter); BIO12 (Annual Precipitation); BIO13 (Precipitation of Wettest Month); BIO14 (Precipitation of Driest Month); BIO15 (Precipitation Seasonality (Coefficient of Variation)); BIO16 (Precipitation of Wettest Quarter); BIO17 (Precipitation of Driest Quarter); BIO18 (Precipitation of Warmest Quarter); and BIO19 (Precipitation of Coldest Quarter). The bioclimatic variables and altitude were selected to describe the environmental characteristics of the sampling sites for the principal component (PC) analysis and for the calculation of environmental distances. Although some bioclimatic variables were highly correlated, all were included in the further statistical analysis, as they describe environmental characteristics of the studied populations and interpret the differences on the population level to a higher degree.

\subsection{Morphometric Analysis}

Two leaves from the central part of the shoot were selected at random for further analysis, as those are generally considered to be the most uniform ones [53] with a total of 40 leaves per shrub. In total, 68 individuals were sampled, resulting in morphological data for 2720 leaves. The measurements were carried out using the WinFolia program [54]. Nine phenotypic traits were selected for measurement (Figure 2B). The shape of the leaf 
was described as the angle closed by the main leaf vein and the line defined by the leaf blade base and a point on the leaf margin, at 10\% (LA1) and 25\% (LA2) of leaf blade length, and the form coefficient (FC). The remaining six parameters indicated the general leaf dimensions: leaf area (LA); leaf length (LL); maximum leaf width (MLW); leaf length, measured from the leaf base to the point of maximum leaf width (PMLW); leaf blade width at $90 \%$ of leaf blade length (LW2) and petiole length (PL). After the above mentioned nine traits were measured, leaves were dried for 24 hours at $105^{\circ} \mathrm{C}$ and weighed. The weight of dried leaves was used to calculate specific leaf area (SLA), by dividing mean leaf area by mean leaf dry weight $\left(\mathrm{cm}^{2} \mathrm{~g}^{-1} \mathrm{dw}\right)$.

\subsection{Statistical Analysis}

All data were standardised before analysis to avoid the possible influence of variation resulting from various types of traits. To assess the possibility of conducting multivariate statistical analyses and parametric tests, the symmetry, unimodality and homoscedasticity of data were verified [55]. Assumptions of normality were checked using the Shapiro-Wilk test, and the assumption of homogeneity of variance using Levene's test.

Arithmetic mean, standard deviation, minimum and maximum value and coefficient of variation were calculated for the particular trait for each population in order to determine the range of their variation. To detect the level of inter- and intra-population variability, hierarchical analysis of variance was used. The analysed factors were populations and shrubs within populations (shrub factor nested inside the population factor). In addition, statistically significant differences between all pairs of populations were identified using Fisher's LSD multiple comparison test, at $p \leq 0.05$. Descriptive statistics and hierarchical analysis of variance were carried out using the STATISTICA software package version 13 [56].

Specific leaf area (SLA) for all of the 12 studied Salix triandra populations was shown in a form of a bar chart, with additional vertical error bars representing standard deviations. One-way analysis of variance was used to test differences between populations.

To analyse structure of the studied populations, several multivariate statistical methods were performed. The K-means method was applied to detect phenotypic structure and define the number of K-groups that best explained the morphological variation of populations [57-60]. If the proportion of a specific population was equal to or higher than 0.7 , that population was assumed to belong to one cluster, and if it was lower than 0.7, that population was considered to be of mixed origin [60]. A dendrogram of the closest Euclidean distances on the basis of the unweighted pair-group method using arithmetic means (UPGMA) was constructed to check the structure between the studied populations. Furthermore, discriminant analysis was performed to evaluate the utility and importance of measured leaf traits by determining which were most useful in maximally discriminating the populations, and to eliminate possible redundant variables. The proportion of individuals correctly classified into the studied populations was determined using classificatory discriminant analysis. The above multivariate statistical analyses were conducted using the "MorphoTools" R scripts in R Version 3.2.2 [61] following the manual of Koutecký [62].

To test correlations between morphometric, geographic and environmental data three different matrices were calculated. Climate data $[52,63]$ and altitude values, retrieved from GPS data recorded during fieldwork, were used to calculate the environmental distance matrix. Environmental differences were calculated as the Euclidian distance between the population means for the first three principal components of the principal component (PC) analysis. Squared Mahalanobis distances between the populations were computed to obtain a matrix of morphometric distances among the studied populations. Geographic distances were calculated from the latitude and longitude of the site of sample collection. Finally, to assess isolation by distance (IBD) and isolation by environment (IBE), response matrix (morphological differences) was compared to the two predictor matrices (climate differences and geographic distance) using simple Mantel tests [64-66]. The significance level was assessed after 10,000 permutations, as implemented in NTSYS-pc Version 2.21L [67]. 


\section{Results}

\subsection{Climate Differences among Sampling Sites}

Nineteen bioclimatic variables and altitudes were used to describe the environmental differences between 12 studied populations (Table S1). The first principal component (PC1) explained $67.53 \%$ of the total variation and clearly separated the karstic (P02, P03, P04, P05, P06, P07 and P08) populations from higher altitudes from other continental (P09, P10, P11 and P12) and sub-Mediterranean (P01) populations (Figure 1B and Table S2). Named principal component demonstrated strong negative correlation with altitude, $\mathrm{BIO} 3, \mathrm{BIO} 12$, $\mathrm{BIO} 13, \mathrm{BIO} 14, \mathrm{BIO} 16, \mathrm{BIO} 17, \mathrm{BIO} 18$ and $\mathrm{BIO} 19$ and positive with $\mathrm{BIO} 1, \mathrm{BIO} 4, \mathrm{BIO} 5, \mathrm{BIO}$, BIO9 and BIO10. The second principal component explained $19.45 \%$ of the total variation and was negatively correlated with BIO6 and BIO11, while positively correlating with BIO7.

\subsection{Populations' Phenotypic Diversity}

Our results clearly demonstrate high phenotypic diversity of the almond-leaved willow populations (Table 1). When observing the values of morphometric traits' analysis, three populations stand out. The karstic population P04 was characterised by having minimum values for six out of the nine measured traits (LA, LL, MLW, PMLW, LW2 and PL). On the other hand, the lowland population P11 demonstrated the highest values for five traits (LA, LL, MLW, LW2 and PL), whereas the three traits describing the leaf shape (FC, LA1 and LA2) had maximum values in the karstic population P08. The minimum values for the leaf shape traits were measured in populations P10 (LA2 and FC), P12 (LA2) and the sub-Mediterranean population, P01 (LA1). Four karstic populations (P02, P03, P07 and P08) and one lowland (P09) had intermediate values for all of the nine parameters. The most variable population was undoubtedly the single sub-Mediterranean population P01, with seven out of nine traits demonstrating the highest values of the coefficient of variation for both traits describing the shape and the size of the leaves (LA, FC, LL, MLW, LA1, LA2 and PL). The least variable population, with minimum variability for four traits (LA, MLW, PMLW and LW2), was P04.

When observing the SLA values (Figure 3), P04 demonstrated lowest mean values $\left(93.82 \mathrm{~cm}^{2} \mathrm{~g}^{-1}\right)$, whereas P12 demonstrated the highest $\left(162.73 \mathrm{~cm}^{2} \mathrm{~g}^{-1}\right)$. Mean data distribution followed a pattern of the distribution for LA, with P11 and P01 having the second and third highest values and P07 as the second lowest value (Figure 3). In addition, for values of SLA one-way analysis of variance (ANOVA) showed significant differences between studied populations.

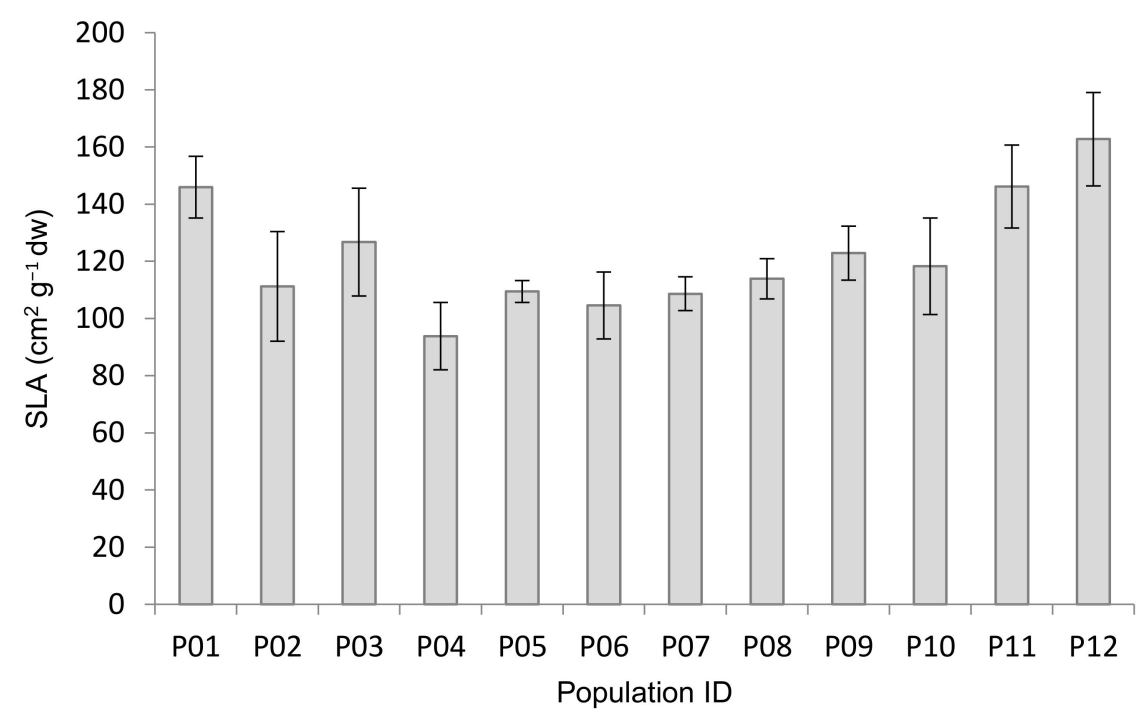

Figure 3. Results of the calculated specific leaf area (SLA; $\mathrm{cm} 2 \mathrm{~g}^{-1} \mathrm{dw}$ ) and error bars representing standard deviations for each of the studied populations. Population acronyms are as in Figure 1. 
Table 1. Descriptive statistics for analysed traits of Salix triandra leaves from 12 studied populations. Populations' acronyms as in Figure 1. Leaf morphometric traits acronyms as in Figure 2. Maximal and minimal values for arithmetic mean $(\mathrm{M})$ and coefficient of variation $(\mathrm{CV})$ are highlighted with red and green colour, respectively. $\mathrm{M}$-arithmetic mean; SD—standard deviation; Min—minimal value; Max-maximal value; $\mathrm{CV}$-coefficient of variation (\%).

\begin{tabular}{|c|c|c|c|c|c|c|c|c|c|c|}
\hline $\begin{array}{c}\text { Population } \\
\text { ID }\end{array}$ & $\begin{array}{c}\text { Descriptive } \\
\text { Parameter }\end{array}$ & $\begin{array}{c}\text { LA } \\
\left(\mathrm{cm}^{2}\right)\end{array}$ & FC & LL (cm) & $\begin{array}{l}\text { MLW } \\
(\mathrm{cm})\end{array}$ & $\begin{array}{c}\text { PMLW } \\
\text { (cm) }\end{array}$ & $\begin{array}{l}\mathrm{LW} 2 \\
(\mathrm{~cm})\end{array}$ & LA1 $\left(^{\circ}\right)$ & LA2 $\left(^{\circ}\right)$ & PL (cm) \\
\hline \multirow{2}{*}{ P01 } & $\mathrm{M}$ & 5.47 & 0.37 & 5.75 & 1.33 & 2.78 & 0.46 & 28.95 & 20.17 & 0.92 \\
\hline & CV (\%) & 45.15 & 21.20 & 24.56 & 21.87 & 30.05 & 28.03 & 20.21 & 20.78 & 32.94 \\
\hline \multirow{2}{*}{ P02 } & $\mathrm{M}$ & 4.00 & 0.39 & 4.85 & 1.18 & 2.02 & 0.34 & 34.88 & 22.79 & 0.76 \\
\hline & CV (\%) & 23.71 & 19.04 & 14.74 & 14.98 & 18.51 & 32.79 & 9.81 & 15.15 & 21.47 \\
\hline \multirow{2}{*}{ P03 } & $\mathrm{M}$ & 3.84 & 0.37 & 4.91 & 1.11 & 2.09 & 0.33 & 32.49 & 21.05 & 0.56 \\
\hline & CV (\%) & 26.94 & 16.78 & 16.13 & 15.23 & 19.86 & 31.17 & 11.12 & 12.56 & 23.68 \\
\hline \multirow[b]{2}{*}{ P04 } & $\mathrm{M}$ & 2.60 & 0.39 & 3.90 & 0.95 & 1.78 & 0.31 & 32.58 & 20.99 & 0.38 \\
\hline & CV (\%) & 21.48 & 11.04 & 13.28 & 11.85 & 15.38 & 17.95 & 9.46 & 9.70 & 23.08 \\
\hline \multirow{2}{*}{ P05 } & M & 3.75 & 0.40 & 4.60 & 1.15 & 2.06 & 0.34 & 34.80 & 22.67 & 0.72 \\
\hline & CV (\%) & 24.15 & 13.13 & 11.11 & 16.02 & 16.80 & 31.12 & 9.00 & 10.60 & 15.91 \\
\hline \multirow{2}{*}{ P06 } & M & 4.47 & 0.40 & 5.00 & 1.26 & 2.08 & 0.38 & 35.51 & 23.29 & 0.93 \\
\hline & CV (\%) & 29.41 & 12.84 & 15.23 & 17.71 & 19.60 & 27.87 & 10.00 & 10.49 & 22.95 \\
\hline \multirow{2}{*}{ P07 } & M & 3.48 & 0.36 & 4.69 & 1.03 & 2.02 & 0.32 & 32.39 & 20.73 & 0.83 \\
\hline & CV (\%) & 25.35 & 11.45 & 13.20 & 16.57 & 19.84 & 20.75 & 9.27 & 12.87 & 23.37 \\
\hline \multirow{2}{*}{ P08 } & M & 3.95 & 0.41 & 4.63 & 1.18 & 1.86 & 0.38 & 37.01 & 24.01 & 0.64 \\
\hline & CV (\%) & 23.13 & 8.99 & 11.75 & 13.46 & 21.91 & 25.41 & 7.78 & 8.15 & 18.25 \\
\hline \multirow{2}{*}{ P09 } & M & 5.08 & 0.34 & 5.78 & 1.20 & 2.33 & 0.36 & 32.56 & 20.10 & 0.84 \\
\hline & CV (\%) & 32.14 & 9.42 & 15.58 & 16.05 & 31.06 & 31.31 & 10.90 & 10.45 & 26.81 \\
\hline \multirow{2}{*}{ P10 } & M & 3.95 & 0.33 & 5.25 & 1.04 & 2.16 & 0.32 & 31.70 & 19.04 & 0.80 \\
\hline & CV (\%) & 21.62 & 15.03 & 11.51 & 14.94 & 18.60 & 25.55 & 12.31 & 13.87 & 23.98 \\
\hline \multirow[b]{2}{*}{ P11 } & M & 7.76 & 0.35 & 7.00 & 1.58 & 2.48 & 0.47 & 34.59 & 22.22 & 1.21 \\
\hline & CV (\%) & 25.04 & 18.32 & 13.28 & 17.04 & 22.99 & 26.19 & 10.18 & 13.50 & 20.77 \\
\hline \multirow{2}{*}{ P12 } & M & 6.75 & 0.33 & 6.90 & 1.39 & 2.58 & 0.39 & 33.49 & 19.89 & 1.02 \\
\hline & CV (\%) & 23.23 & 20.04 & 12.37 & 17.22 & 22.98 & 28.10 & 17.06 & 18.65 & 21.82 \\
\hline \multirow{5}{*}{ Total } & $\mathrm{M}$ & 4.41 & 0.37 & 5.15 & 1.19 & 2.15 & 0.36 & 33.67 & 21.62 & 0.78 \\
\hline & $\mathrm{SD}$ & 1.75 & 0.06 & 1.10 & 0.24 & 0.55 & 0.11 & 4.31 & 3.23 & 0.26 \\
\hline & Min & 1.47 & 0.17 & 2.81 & 0.58 & 0.92 & 0.23 & 17.00 & 12.00 & 0.13 \\
\hline & Max & 16.06 & 0.66 & 10.47 & 2.35 & 6.40 & 0.89 & 48.00 & 35.00 & 2.18 \\
\hline & CV (\%) & 39.74 & 16.78 & 21.39 & 20.37 & 25.51 & 30.82 & 12.80 & 14.92 & 33.50 \\
\hline
\end{tabular}

Significant differences between all of the researched populations were determined for all nine morphometric leaf traits (Table 2). A larger proportion of total variability of the traits related to leaf length and surface area (LA, LL and PL) was assigned to interpopulational variability, whereas the traits describing the leaf shape (FC, LA1 and LA2) were defined by having the larger proportion of total variability linked to intra-populational differences, although a large proportion was linked to error as well. The three traits related to leaf width (MLW, PMLW and LW1) showed no clear trend in distribution of proportion of total variability among the three components of variance. PMLW and LW2 had the largest proportion assigned to the error component, whereas the remaining proportion was similarly divided between intra- and inter-populational variability. MLW, on the other hand, had proportions of total variability almost equally divided between the three components of variability, $38.55 \%, 26.82 \%$ and $34.63 \%$ for inter-, intra-populational and error components, respectively. 
Table 2. Results of the hierarchical analysis of variance. Leaf morphometric traits acronyms as in Figure 2.

\begin{tabular}{|c|c|c|c|c|c|}
\hline Trait & Components of the Variance & df & $\mathbf{F}$ & $\begin{array}{l}\text { Percent of } \\
\text { Variability }\end{array}$ & $p$-Value \\
\hline \multirow{3}{*}{ LA } & Among populations & 11 & 15.28 & 53.31 & $<0.01$ \\
\hline & Within populations & 56 & 13.75 & 15.43 & $<0.01$ \\
\hline & Error & & & 31.26 & \\
\hline \multirow{3}{*}{$\mathrm{FC}$} & Among populations & 11 & 2.66 & 14.41 & $<0.01$ \\
\hline & Within populations & 56 & 26.94 & 41.85 & $<0.01$ \\
\hline & Error & & & 43.74 & \\
\hline \multirow{3}{*}{$\mathrm{LL}$} & Among populations & 11 & 19.77 & 57.53 & $<0.01$ \\
\hline & Within populations & 56 & 12.12 & 12.26 & $<0.01$ \\
\hline & Error & & & 30.21 & \\
\hline \multirow{3}{*}{ MLW } & Among populations & 11 & 6.78 & 38.55 & $<0.01$ \\
\hline & Within populations & 56 & 21.60 & 26.82 & $<0.01$ \\
\hline & Error & & & 34.63 & \\
\hline \multirow{3}{*}{ PMLW } & Among populations & 11 & 6.24 & 24.48 & $<0.01$ \\
\hline & Within populations & 56 & 10.74 & 21.54 & $<0.01$ \\
\hline & Error & & & 53.98 & \\
\hline \multirow{3}{*}{ LW2 } & Among populations & 11 & 3.77 & 15.65 & $<0.01$ \\
\hline & Within populations & 56 & 12.06 & 23.81 & $<0.01$ \\
\hline & Error & & & 60.54 & \\
\hline \multirow{3}{*}{ LA1 } & Among populations & 11 & 3.39 & 14.75 & $<0.01$ \\
\hline & Within populations & 56 & 25.34 & 43.36 & $<0.01$ \\
\hline & Error & & & 41.89 & \\
\hline \multirow{3}{*}{ LA2 } & Among populations & 11 & 2.96 & 16.40 & $<0.01$ \\
\hline & Within populations & 56 & 33.39 & 46.41 & $<0.01$ \\
\hline & Error & & & 37.19 & \\
\hline \multirow{3}{*}{ PL } & Among populations & 11 & 11.63 & 52.82 & $<0.01$ \\
\hline & Within populations & 56 & 24.13 & 22.61 & $<0.01$ \\
\hline & Error & & & 24.56 & \\
\hline
\end{tabular}

$\mathrm{K}$-means clustering inferred the origin of the populations and revealed three clusters, marked in green, blue and yellow in Figure 1A. Easternmost populations of P11 and P12 demonstrated origin completely assigned to cluster A (green), whereas population P01 showed a partial cluster affiliation belonging to cluster A (proportion of membership: 0.6) and cluster B (proportion of membership: 0.4). cluster B (blue) was defined by karstic populations of P02 (proportion of membership: 0.9) and P07 (proportion of membership: 1.0), and the lowland populations of P09 (proportion of membership: 0.8) and P10 (proportion of membership: 0.7). Additionally, three other karstic populations: P03, P05 and P06, showed mixed origin. The third cluster ( $\mathrm{C}$, yellow) encompassed two karstic populations, P04 (proportion of membership 1.0) and P08 (proportion of membership: 0.7), with P03, P05 and P06 demonstrating a certain proportion of their origin assigned to Cluster C.

As revealed by UPGMA clustering, researched populations grouped into two clusters with Cluster 1 further divided into two subclusters (Figure S1). This division shares great similarities with the Clusters A, B and C, revealed in the K-means method. The first subcluster of Cluster 1 comprised of two lowland populations, P09 and P10, as well as the karstic populations P03 and P07. The second subcluster was defined by having the remaining karstic populations, with P02 and P05 as being the most similar, whereas the P04 demonstrated the greatest difference within this second subcluster. In the Cluster 2 , the easternmost populations P11 and P12 grouped with P01, indicating a lack of clear geographic structuring, but potential great influence of common ecological conditions.

To examine which of the leaf traits were statistically significant between the individual populations, a multiple comparison Fisher's LSD test was performed (Table S3). The unique character of the P01 population was revealed, with this population having the largest number of significantly different leaf trait values compared to all remaining populations. The easternmost populations, P11 and P12, were highly significantly different compared to the 
other populations. However, it was found that only four traits were significantly different between populations P01 and P12, while P01 and P11 differed significantly in six traits. Furthermore, populations P11 and P12, also had only four significantly different traits, confirming their similarity. The karstic population, P05, shared common characteristics with populations $\mathrm{P} 02$ and $\mathrm{P} 03$, as they did not show significant trait differences. In addition, P02 and P05 showed similarity with populations P07 and P08, as they did not have differentiating traits. P04 and P08, although belonging to the same cluster and subcluster, were significantly differ one from another in six out of nine measured traits. When observing overall results, petiole length (PL) proved to be the most significantly differentiating leaf trait.

Six out of nine measured leaf traits have shown to be significant in discriminating the researched almond-leaved willow populations. The greatest discriminating power was noted for traits PMLW and PL, with partial Wilks' lambda values of 0.49 and 0.50 , respectively (Table S4). Other traits' significance, in descending order, is as follows: LA, LA2, LL and FC. Traits MLW and LW2, as well as LA1, have not shown significant discriminant power among the populations. Overall, for nine traits and 12 populations, the canonical discriminant analysis resulted in nine discriminant functions, with the first three functions demonstrating eigenvalues greater than 1 . The first discriminant function, accounting for $63.8 \%$ of total variability, was the best discriminator between the easternmost populations of P11 and P12 and the remaining 10 populations (Figures 4 and 5). The next two functions contributed significantly less to the overall variability, accounting for $17.8 \%$ and $8.4 \%$ of total variability, respectively. The second function discriminated the P04 population best, and the third function discriminated the P01 population best. Generated values of the discriminant functions are shown on the shrub level, which are grouped based on the population affiliation. A very clear separation of populations P11 and P12 along the first axis and populations P04 and P01 along the second and third axis was observed. The classification accuracy for all of the populations was $80.9 \%$. The highest classification accuracy was noted for individuals from the population P11 (100\%), whereas the accuracy for the individuals of the population P06 amounted to only 50\%.

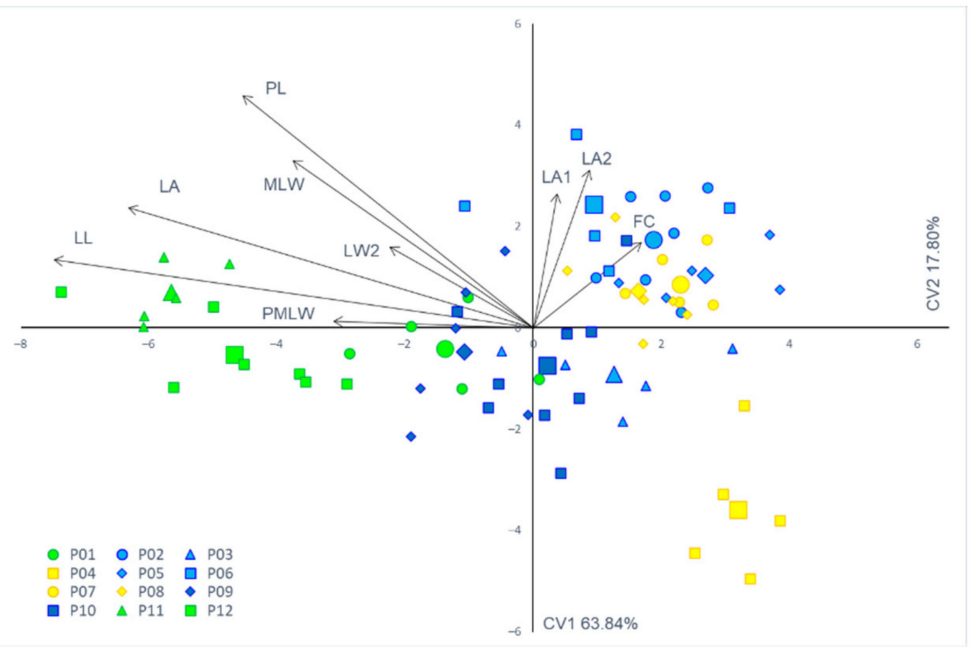

Figure 4. The first two canonical variates of the canonical discriminant analysis (CV1 and CV2) of 12 Salix triandra populations based on nine morphological traits. Each individual shrub is indicated by a small sign, while the population barycenters are represented by larger ones. The colour of the signs is related to the three groups of populations detected from K-means clustering method (cluster A-green; cluster B-blue; cluster C-yellow). Population acronyms are as in Figure 1. Acronyms for leaf morphometric traits are as in Figure 2. 


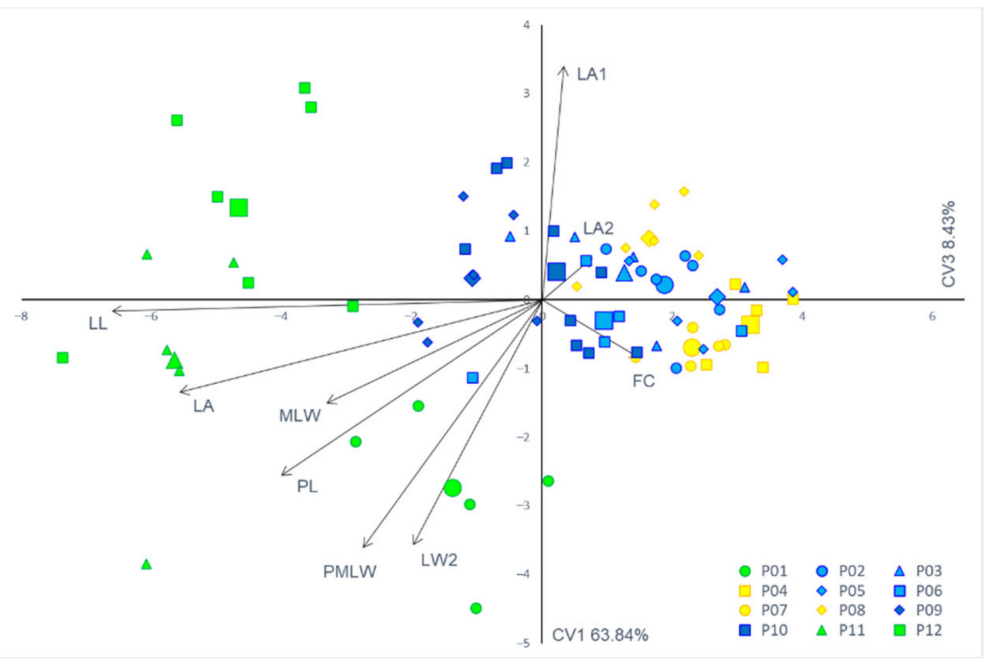

Figure 5. The first and third canonical variates of the canonical discriminant analysis (CV1 and CV3) of 12 Salix triandra populations based on nine morphological traits. Each individual shrub is indicated by a small sign, while the population barycentres are represented by larger ones. The colour of the signs is related to the three groups of populations detected from K-means clustering method (cluster A-green, cluster B-blue; cluster C-yellow). Populations' acronyms as in Figure 1. Acronyms for leaf morphometric traits as in Figure 2.

The analysed populations showed significant correlations between both geographic and phenotypic distances (isolation by distance (IBD), $(r=0.516, p=0.0077)$ (Figure 6A)) and between environmental and phenotypic distances (isolation by environment (IBE), $(r=0.493, p=0.0037)$ (Figure 6B)).
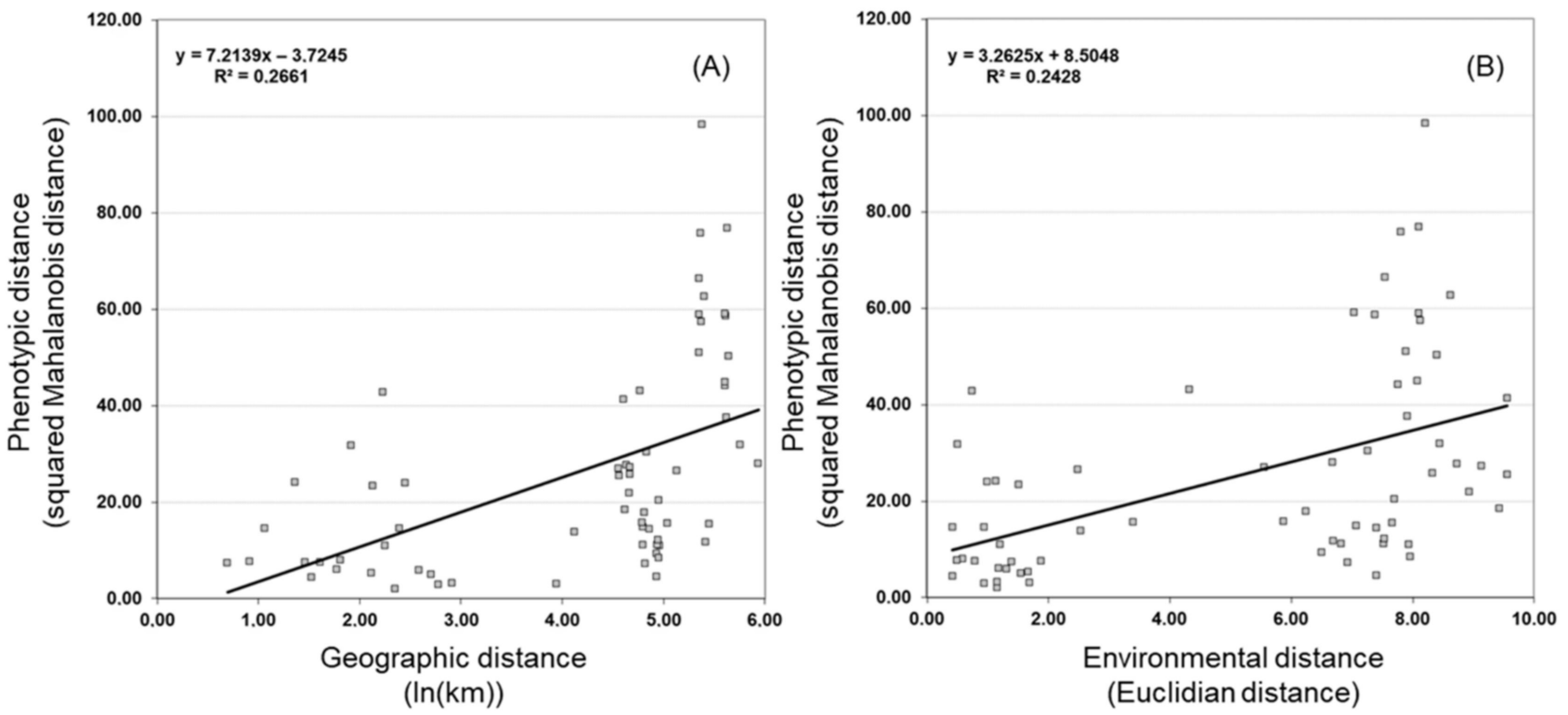

Figure 6. Isolation-by-distance (IBD) and isolation-by-environmental-distance (IBE) in almondleaved willow populations. Scatter plots of simple Mantel tests showing the relationships between: (A) geographic and phenotypic distances $(\mathrm{r}=0.516, p=0.0077)$ and $(\mathbf{B})$ environmental and phenotypic distances $(r=0.493, p=0.0037)$.

\section{Discussion}

Almond-leaved willow research has been scarce, with generally little previously published data on the species [47-50,68]. Krüssmann [68] reported leaf length (LL) values in the range of 5 to $10 \mathrm{~cm}$. Similarly, Bartha [69] reported leaves to be $3-10(-15) \mathrm{cm}$ long and 
(2-) 3-7 times narrower than long. Our mean values of LL $(5.15 \mathrm{~cm})$ and MLW $(1.19 \mathrm{~cm})$ fall within these data ranges. In addition, mean petiole length (PL) measured for the 12 researched populations was $0.78 \mathrm{~cm}$, which also confirms the previously reported values for PL in range of $0.5-1.5 \mathrm{~cm}[69]$.

When observing the variability of leaf traits, a difference between traits related to leaf size and leaf shape can be noticed. The range of coefficient of variation values for leaf size related traits is $20.37 \%$ to $39.74 \%$, whereas the leaf shape traits are less variable, with a range of $12.80 \%$ to $16.78 \%$, i.e., traits describing leaf size are more variable. The same pattern has been confirmed for other Salix species as well [40,41]. Willows are generally a variable genus, with leaf morphology and anatomy showing high levels of adaptability [39]. Almondleaved willow is no exception, being previously noted as extremely variable in terms of leaf and shoot morphology [45]. Similarly, a number of poplar (Populus spp.) species, also members of the Salicaceae family, have been shown to have a high degree of leaf size variability $[42,45,70-73]$. This trend seems to extend to other pioneer species, including black (Alnus glutinosa (L.) Gaertn.) and grey (A. incana (L.) Moench) alder $[60,74,75]$, and paper (Betula papyrifera Marsh.), silver (B. pendula L.) and yellow birch (B. alleghaniensis Britton) [76-78]. As a pioneer species, fast establishment in a new environment is the key to survival and may depend on the morphology of the leaves, primarily leaf area [42]. This would make leaf area the key trait, which could explain the high variability of the trait in this research. In addition, crown architecture, with the goal of preventing self-shading, is an important trait of pioneer species, enabling them the optimal growth conditions [79].

When observing individual populations of Salix triandra, P01 (Mirna) was most variable, with the most variable values of both leaf size and leaf shape traits. This could be attributed to the relatively high humidity of the sub-Mediterranean climate, as well as higher temperatures, two factors that positively influence leaf variability [80]. This is confirmed by the bioclimatic data for the given population, as it is the warmest out of all studied populations $\left(13.3^{\circ} \mathrm{C}\right)$ and has a relatively high precipitation rate $(1015 \mathrm{~mm})$ (Table S1). In addition, higher variability of this population could be the result of increased nutrient content in the soil, causing more variation in the production of leaf tissue. The effect of increased nutrient content in soils has a stronger effect on shrubs than on trees, with shrub species, such as almond-leaved willow, positively reaching to higher nutrient levels [81]. Unlike previously mentioned sub-Mediterranean population, karstic population P04 (Vitunj) demonstrated lowest variability on the population level, with the second least variable populations being another karstic population, P08 (Zagorska Mrežnica south). Unlike lowland populations, these populations grow on nutrient-poor soils, out of the reach of the floodwaters, and are often geographically more separate, making gene flow less likely. Furthermore, more demanding conditions may have favoured a smaller number of individuals, leading to reduction of the variation in the populations' gene pool.

Dioecious plants are known to display modest dimorphism in vegetative and phenological traits [82] and such differences might have influenced leaf morphology of almondleaved willow as well. The gender-based differences are well-documented, but primarily relate to plant physiology [83], with influence on carbon gain [84], stress tolerance [85], photochemical output [86] and herbivory defence [87]. In some cases, gender-related plant responses are influenced by the environment $[85,88,89]$. In addition, reported data on the influence of gender on morphology is inconsistent and vary from having influence [90-93], being of uncertain influence [94-96] to no influence at all [97]. These inconsistencies can be particularly observed in the Populus genus, closely related genus to willows. Female plants of Chinese white poplar demonstrated lower values for specific leaf area (SLA) and leaf length (LL) [98], with clear distinction between the genders. On the other hand, $P$. trichocarpa Torr. et Gray ex Hook. and P. balsamifera L. demonstrated no differences among them [99]. In the Salix species, the results are inconclusive, with S. udensis Trautv. et C.A. Mey. not demonstrating any differences in growth [100], whereas S. glauca L. male plant demonstrated better drought tolerance due to lower stomatal conductance and transpiration rates [101]. Considering the high levels of inter-population variability measured 
in this research, the influence of gender is likely lesser than that of the environment. With the varying levels of influence of gender on the plant morphology in mind, we cannot exclude the possibility of such influence on our populations. Such investigation would be beneficial for broader understanding of the interactions between the genetic background, the environment and gender-related differences of the species in the future.

The populations included in this research have demonstrated inter-population morphometric variability of traits related to leaf size greater than expected, at the same time indicating low intra-population variability. Such great trait variability among small populations can be attributed to uniform habitat conditions in each population, as well as the founder effect, which most likely influenced the phenotypic variability. The founder effect is a specific form of establishment of a new population by a limited number of individuals, inevitably representing only a small fraction of the original population variability [102]. Almond-leaved willow is known for its propensity to vegetative propagation from brokenoff branches which, in addition to habitats along the rivers, could explain the ease of establishing a new colony from a singular or small number of individuals. In addition, the size and large number of seeds produced by willows mean some of the seeds could easily travel downstream or be carried by the wind to a favourable location with stable conditions, where they could grow into new individuals. Once sexually mature, these individuals could continue to expand the population not only by vegetative self-propagation, but by seeds as well, thus forming a new population. A small population size growing in stable and uniform environmental conditions additionally guarantees uniform leaf traits among individuals within each individual population. This theory is supported by similar occurrences in other pioneer species, with leaf morphology correlating to the specific environments [78], demonstrating additionally greater inter-population variability [76] Interaction between genetic and environmental factors often results in variation in leaf size and shape traits, which play a crucial role in a plant's ability to capture light and photosynthesise, i.e., in overall plant's fitness [16,27,103,104]. Accordingly, adjustment of leaf morphology by the plants in the variable environmental conditions is the main mechanism in plant adaptation [105]. High levels of variability in these traits, therefore, can be expected and are supported by our findings.

Grouping of the populations into three clusters, with grouping predominantly explained by common ecological conditions, was revealed. The easternmost lowland populations, P11 and P12, and westernmost, mixed-origin population, P01, grouped together, signifying the common denominator to be the ecological conditions, e.g., habitat. P11 and P12 grow in the riparian zone of river Sava, one of the larger rivers of Pannonian catchment, which forms extensive floodplains. Additionally, these populations show high annual mean temperatures of 11.2 and $11.3{ }^{\circ} \mathrm{C}$, respectively. The westernmost population, P01 (Mirna), is named after a river in the northern Adriatic catchment and grows under the influence of the sub-Mediterranean climate, characterised by the highest mean annual temperature, with $13.3^{\circ} \mathrm{C}$. It is therefore possible to presume a river regime of flooding and the high temperatures conditions, in addition to fluvial soils, form the constant and similar conditions, favouring similar morphological adaptations of otherwise disjunct populations. In addition, nutrient-rich soils and constant conditions of soil humidity can directly influence the repeating pattern of trait values in populations from similar habitats, as it has been previously reported in numerous studies for a wide array of living organisms [106]. On the other hand, the karstic populations included in this research did not form a singular, well-defined cluster. These small populations grow on mostly gravelly, often skeletal soils in less stable conditions, with fluctuating water levels between winter and summer. As a result, although geographically close, these populations have adapted to micro-locations and conditions and thus some of them, such as the populations P04 (Vitunj) and P06 (Zagorska Mrežnica south), have significantly different values for most of the measured traits. This is supported by our field observations for population P04 (Vitunj). Unlike other karstic populations, almond-leaved willows in this micro-location grow on a wet meadow, close to but not along the rivulet Vitunjčica. The fact that the plants do not 
grow directly on the water's edge most likely led to slight but noticeable differences in soil humidity and perhaps soil type, which in turn have caused specific trait values and variability.

Same differentiation between the karstic and lowland populations can be corrobo-rated by SLA data, which followed the same trend as LA values. High SLA values in low-land populations, characterised by humid and nutrient-rich soils, and lower values in karstic populations found on drier, nutrient-poor soils, are in agreement with previous data on positive correlation between increased humidity and nutrient content and SLA [107-109]. SLA is known to be a good predictor of plant growth, as it correlates with the growth parameters of the whole plant [110]. In addition, SLA is a good indicator of the ability of plants to utilise resources available from the environment, with differences between high-SLA and low-SLA species [111]. High-SLA species are usually found in nutrient-rich habitats, where they can afford the shortened life span of leaves. Low-SLA species, however, usually grow on nutrient-poor habitats and thus have more dry matter per leaf, keeping leaves for a number of seasons [111,112]. Therefore, almond-leaved willow would be classified as high-SLA species, a fact supported by populations found on the nutrient-rich soils having the highest SLA values.

The results of this research indicated the existence of both isolation by distance (IBD) and isolation by environment (IBE) patterns. These models refer to morphological variability resulting from geographical (IBD) or environmental (IBE) distances between the populations $[113,114]$. In other words, the differences in altitude and climatic conditions, in addition to geographical distances between the populations, were great enough to bring about variations in phenotypic expression of almond-leaved willow shrubs, with a trend of similarities between ecologically and geographically closer populations. The certain gene flow pattern can influence species' populations in various ways, from increasing the genetic variation and population size, to weakening adaptive genetic combinations, leading to a reduction of population size [115]. In small populations, such as those covered in our study, gene flow between similar environments may increase population size and introduce new, locally beneficial alleles $[116,117]$, which will allow plants to adapt to rapidly changing habitats due to climate change. The influence of both patterns on phenotypic variability of woody species has been previously reported by several authors, where geographically closer and environmentally similar populations had similar morphotypes [60,118-122]. This was further confirmed in a comprehensive review by Sexton et al. [115], who discovered that both models have a significant influence in $60 \%$ of the cases. This means that gene flow between populations, and thus their phenotypic similarity, is greater at shorter distances and analogous environments. Therefore, IBD in our study might be caused by limitations in seed and pollen dispersal and drift, while IBE could be present due to non-random mating originating from differences in timing of phenological processes and local adaptation caused by strong selection [115].

\section{Conclusions}

The traits related to leaf size were more significant in describing differences between populations and also had the highest variability. The large differences among the populations are the result of both geographical and environmental distances between them. In addition, considering the small size of the populations, the high variability among the populations can be attributed to the founder effect, which is very likely considering the ease of the almond-leaved willow's propagation. The results of the multivariate statistical methods revealed three groups of populations defined by common environmental conditions and geographical proximity.

Supplementary Materials: The following supporting information can be downloaded at: https: / / www.mdpi.com/article/10.3390/f13030420/s1, Table S1: Sample size (N), geographic coordinates, altitudes and bioclimatic variables for 12 studied Salix triandra populations. Bioclimatic variables: BIO1 (Annual Mean Temperature); BIO2 (Mean Diurnal Range (Mean of monthly (max temp - min temp)); BIO3 (Isothermality $(\mathrm{BIO} 2 / \mathrm{BIO} 7)(\times 100))$; BIO4 (Temperature Seasonality (standard deviation 
$\times 100)$ ); BIO5 (Max Temperature of Warmest Month); BIO6 (Min Temperature of Coldest Month); BIO7 (Temperature Annual Range (BIO5-BIO6)); BIO8 (Mean Temperature of Wettest Quarter); BIO9 (Mean Temperature of Driest Quarter); BIO10 (Mean Temperature of Warmest Quarter); BIO11 (Mean Temperature of Coldest Quarter); BIO12 (Annual Precipitation); BIO13 (Precipitation of Wettest Month); BIO14 (Precipitation of Driest Month); BIO15 (Precipitation Seasonality (Coefficient of Variation)); BIO16 (Precipitation of Wettest Quarter); BIO17 (Precipitation of Driest Quarter); BIO18 (Precipitation of Warmest Quarter); BIO19 (Precipitation of Coldest Quarter). Populations: P01—Mirna; P02-Gomirje; P03-Perić most; P04-Vitunj; P05-Dobra mlin; P06-Zagorska Mrežnica north; P07-Sabljaci; P08-Zagorska Mrežnica south; P09—Lonjsko polje; P10-Narta; P11—Jelas polje; P12-Županja; Table S2: Pearson correlation coefficients between altitude and 19 bioclimatic variables and scores of the first four principal components. Bioclimatic variables acronyms as in Table S1; Table S3: Results of the Fisher's LSD test. Leaf morphometric traits: LA-leaf area; FC—form coefficient; LL_leaf length; MLW_-maximum leaf width; PMLW_leaf length, measured from the leaf base to the point of maximum leaf width; LW2-leaf blade width at $90 \%$ of leaf blade length; LA1 - angle closed by the main leaf vein (the centre of leaf blade) and the line connecting the leaf blade base to a set point on the leaf margin at $10 \%$ of total leaf blade length; LA2 - angle closed by the main leaf vein (the centre of leaf blade) and the line connecting the leaf blade base to a set point on the leaf margin at $25 \%$ of total leaf blade length; and PL-petiole length. Population acronyms are as in Table S1; Figure S1: Tree diagram of researched 12 Salix triandra populations. The unweighted pair-group method with arithmetic mean (UPGMA) was used to join the clusters, and the Euclidean distance to define the distance between the studied populations. Population acronyms are as in Table S1; Table S4: Results of the stepwise discriminant analyses for studied morphometric traits.

Author Contributions: Conceptualisation, K.T., Z.Š., A.V., M.I., R.S. and I.P.; methodology, Z.Š., M.I. and I.P.; formal analysis, Z.Š. and I.P.; investigation, K.T., A.V., R.S. and I.P.; writing-original draft preparation, K.T., A.V. and I.P.; writing-review and editing, Z.Š., M.I. and R.S.; visualisation, Z.Š. and I.P. All authors have read and agreed to the published version of the manuscript.

Funding: This research was funded by University of Zagreb financial support.

Acknowledgments: The authors would like to thank the artist Marija Ana Turčić, who created the illustrations represented in Figure 2.

Conflicts of Interest: The authors declare no conflict of interest. The funders had no role in the design of the study; in the collection, analyses, or interpretation of data; in the writing of the manuscript; or in the decision to publish the results.

\section{References}

1. Czesnick, H.; Lenhard, M. Size control in plants-Lessons from leaves and flowers. Cold Spring Harb. Perspect. Biol. 2015, 7, a019190. [CrossRef] [PubMed]

2. Ivanova, L.A.; Ivanov, L.A.; Ronzhina, D.A.; Yudina, P.K.; Migalina, S.V.; Shinehuu, T.; Tserenkhand, G.; Voronin, P.Y.; Anenkhonov, O.A.; Bazha, S.N.; et al. Leaf traits of C3- and C4-plants indicating climatic adaptation along a latitudinal gradient in Southern Siberia and Mongolia. Flora 2019, 254, 122-134. [CrossRef]

3. Adamidis, G.C.; Varsamis, G.; Tiripidis, I.; Dimitrakopoulos, P.G.; Papageorgiou, A.C. Patterns of leaf morphological traits of beech (Fagus sylvatica L.) along an altitudinal gradient. Forests 2021, 12, 1297. [CrossRef]

4. Viscosi, V.; Antonecchia, G.; Lepais, O.; Fortini, P.; Gerber, S.; Loy, A. Leaf shape and size differentiation in white oaks: Assessment of allometric relationships among three sympatric species and their hybrids. Int. J. Plant Sci. 2012, 173, 875-884. [CrossRef]

5. Hagemeier, M.; Leuschner, C. Functional crown architecture of five temperate broadleaf tree species: Vertical gradients in leaf morphology, leaf angle and leaf area density. Forests 2019, 10, 265. [CrossRef]

6. Flexas, J.; Bota, J.; Loreto, F.; Cornic, G.; Sharkey, T.D. Diffusive and metabolic limitations to photosynthesis under drought and salinity in C3 plants. Plant Biol. 2004, 6, 269-279. [CrossRef]

7. Galmés, J.; Flexas, J.; Medrano, H.; Niinemets, Ü.; Valladares, F. Ecophysiology of photosynthesis in semi-arid environments. In Terrestrial Photosynthesis in a Changing Environment. A Molecular, Physiological and Ecological Approach, 1st ed.; Flexas, J., Loreto, F., Medrano, H., Eds.; Cambridge University Press: Cambridge, UK, 2012; pp. 448-464.

8. Poorter, H.; Niinemets, Ü.; Poorter, L.; Wright, I.; Villar, R. Causes and consequences of variation in leaf mass per area (LMA): A meta-analysis. New Phytol. 2009, 182, 565-588. [CrossRef]

9. De la Riva, E.G.; Olmo, M.; Poorter, H.; Ubera, J.L.; Villar, R. Leaf mass per area (LMA) and its relationship with leaf structure and anatomy in 34 Mediterranean woody species along a water availability gradient. PLoS ONE 2016, 11, e0148788. [CrossRef]

10. Yan, Y.; Liu, Q.; Zhang, Q.; Ding, Y.; Li, Y. Adaptation of dominant species to drought in the inner Mongolia grassland-Species level and functional type level analysis. Front. Plant Sci. 2019, 10, 231. [CrossRef] 
11. Purohit, A.N.; Dhyani, P.P. Thermal gradients as control factors for leaf size variations at different altitudes in mountains. Acta Biotheor. 1988, 37, 3-26. [CrossRef]

12. Tian, M.; Yu, G.; He, N.; Hou, J. Leaf morphological and anatomical traits from tropical to temperate coniferous forests: Mechanisms and influencing factors. Sci. Rep. 2016, 6, 19703. [CrossRef] [PubMed]

13. Manishimwe, A.; Ntirugulirwa, B.; Zibera, E.; Nyirambangutse, B.; Mujawamariya, M.; Dusenge, M.E.; Bizuru, E.; Nsabimana, D.; Uddling, J.; Wallin, G. Warming responses of leaf morphology are highly variable among tropical tree species. Forests 2022, 13, 219. [CrossRef]

14. Givnish, T.J. Leaf and canopy adaptations in tropical forests. In Physiological Ecology of Pants of the Wet Tropics; Medina, E., Mooney, H.A., Vázquez-Yánes, C., Eds.; Springer: Dordrecht, The Netherlands, 1984.

15. Fonseca, C.R.; Overton, J.M.; Collins, B.; Westoby, M. Shifts in trait-combinations along rainfall and phosphorus gradients. J. Ecol. 2000, 88, 964-977. [CrossRef]

16. Li, Y.; Zou, D.; Shrestha, N.; Xu, X.; Wang, Q.; Jia, W.; Wang, Z. Spatiotemporal variation in leaf size and shape in response to climate. J. Plant Ecol. 2020, 13, 87-96. [CrossRef]

17. Robakowski, P.; Wyka, T.; Samardakiewicz, S.; Kierzkowski, D. Growth, photosynthesis, and needle structure of silver fir (Abies alba Mill.) seedlings under different canopies. For. Ecol. Manag. 2004, 201, 211-227. [CrossRef]

18. Petritan, A.M.; von Lüpke, B.; Petritan, I.C. Influence of light availability on growth, leaf morphology and plant architecture of beech (Fagus sylvatica L.), maple (Acer pseudoplatanus L.) and ash (Fraxinus excelsior L.) saplings. Eur. J. For. Res. 2009, 128, 61-74. [CrossRef]

19. Souza, M.L.; Duarte, A.A.; Lovato, M.B.; Fagundes, M.; Vallardes, F.; Lemos-Filho, J.P. Climatic factors shaping intraspecific leaf trait variation of a neotropical tree along a rainfall gradient. PLoS ONE 2018, 13, e0208512. [CrossRef]

20. Boutsios, S.; Vidalis, A.; Adamidis, G.C.; Hatziskakis, S.; Varsamis, G.; Tsiripidis, I.; Karanikola, P.; Papageorgiou, A.C. Diversity in shade and light leaf morphology in beech populations of south Rodopi montains. Proc. Natl. Acad. Sci. India Sect. B Biol. Sci. 2021, 91, 53-61. [CrossRef]

21. Danquah, J.A.; Appiah, M.; Ari, P. Eco-geographic in leaf morphology of African Mahogany (Khaya anthoteca and Khaya ivorensis) provenances in Ghana. Eur. J. Sci. Res. 2011, 51, 18-28.

22. Fan, X.; Yan, X.; Qian, C.; Goudia Bachir, D.; Yin, X.; Sun, P.; Ma, X.-F. Leaf variations in a dominant desert shrub, Reaumuria soongarica, adapted to heterogeneous environments. Ecol. Evol. 2020, 10, 10076-10094. [CrossRef]

23. Bar, M.; Ori, N. Leaf development and morphogenesis. Development 2014, 141, 4219-4230. [CrossRef]

24. Tsukaya, H. Leaf shape diversity with an emphasis on leaf contour variation, developmental background, and adaptation. Semin. Cell Dev. Biol. 2018, 79, 48-57. [CrossRef]

25. Wolters, H.; Jürgens, G. Survival of the flexible: Hormonal growth control and adaptation in plant development. Nat. Rev. Genet. 2009, 10, 305-317. [CrossRef] [PubMed]

26. Fritz, M.A.; Rosa, S.; Sicard, A. Mechanisms underlying the environmentally induced plasticity of leaf morphology. Front. Genet. 2018, 9, 478. [CrossRef] [PubMed]

27. Ren, J.; Ji, X.; Wang, C.; Hu, J.; Nervo, G.; Li, J. Variation and genetic parameters of leaf morphological traits of eight families from Populus simonii $\times$ P. nigra. Forests 2020, 11, 1319. [CrossRef]

28. Jump, A.S.; Marchant, R.; Peñuelas, J. Environmental change and the option value of genetic diversity. Trends Plant Sci. 2009, 14, 51-58. [CrossRef]

29. Petrik, P.; Petek, A.; Konôpková, A.; Bosela, M.; Fleischer, P.; Frýdl, J.; Kurjak, D. Stomatal and leaf morphology response of European beech (Fagus sylvatica L.) provenances transferred to contrasting climatic conditions. Forests 2020, 11, 1359. [CrossRef]

30. Liu, W.; Zheng, L.; Qi, D. Variation in leaf traits at different altitudes reflects the adaptive strategy of plants to environmental changes. Ecol. Evol. 2020, 10, 8166-8175. [CrossRef]

31. Liu, Y.; Xiang, H.; Huang, Z.; Xiang, X.; Yu, Y.; Wang, M.; Li, Z. Analysis of leaf-architecture characteristics and ecological adaptability of tree species in the upper reaches of the Chishui river. Ecol. Indic. 2022, 135, 108563. [CrossRef]

32. Forsman, A. Rethinking phenotypic plasticity and its consequences for individuals, populations and species. Heredity 2014, 115, 276-284. [CrossRef]

33. Karrenberg, S.; Edwards, P.; Kollmann, J. The life history of Salicaceae living in the active zone of floodplains. Freshw. Biol. 2002, 47, 733-748. [CrossRef]

34. Drzewiecka, K.; Mleczek, M.; Gąsecka, M.; Magdziak, Z.; Goliński, P. Changes in Salix viminalis L. cv. 'Cannabina' morphology and physiology in response to nickel ions. Hydroponic investigations. J. Hazard. Meter. 2012, 217-218, 429-438. [CrossRef] [PubMed]

35. Gąsecka, M.; Mleczek, M.; Drzewiceka, K.; Magdziak, Z.; Rissmann, I.; Chadzinikolau, T.; Golinski, P. Physiological and morphological changes in Salix viminalis L. as a result of plant exposure to copper. J. Environ. Sci. Health Part A 2012, 47, 548-557. [CrossRef] [PubMed]

36. Özden Keleş, S. Variation in morphological and wood cell traits in coppice stems of Populus nigra L. and Salix alba L. J. For. Sci. 2021, 67, 396-407. [CrossRef]

37. Dickman, D.I.; Kuzovkina, J. Poplars and willows of the world, with emphasis on silviculturally important species. In Poplars and Willows: Trees for Society and the Environment, 1st ed.; Isebrands, J., Richardson, J., Eds.; CABI: Wallingford, UK, $2014 ;$ pp. 8-91. 
38. Cunniff, J.; Purdy, S.J.; Barraclough, T.J.P.; Castle, M.; Maddison, A.L.; Jones, L.E.; Shield, I.F.; Gregory, A.S.; Karp, A. High yielding biomass genotypes of willow (Salix spp.) show differences in below ground biomass allocation. Biomass Bioenergy 2015, 80, 114-127. [CrossRef]

39. Hietala, T.; Mozes, N.; Genet, M.J.; Roseqvist, H.; Laakso, S. Surface lipids and their distribution on willow (Salix) leaves: A combined chemical, morphological and physiochemical study. Colloids Surf. B 1997, 8, 205-215. [CrossRef]

40. Marcysiak, K. Diversity of Salix reticulata (Salicaceae) leaf traits in Europe and its relation to geographical position. Plant Biosyst. 2012, 146, 101-111. [CrossRef]

41. Marcysiak, K. Variation of leaf shape in Salix herbacea in Europe. Plant Syst. Evol. 2012, 298, 1597-1607. [CrossRef]

42. Guet, J.; Fabbrini, F.; Fichot, R.; Sabatti, M.; Bastien, C.; Brignolas, F. Genetic variation for leaf morphology, leaf structure and leaf carbon isotope discrimination in European populations of black poplar (Populus nigra L.). Tree Physiol. 2015, 35, 850-863. [CrossRef]

43. Ye, M.; Gao, P.; Jiang, P.; Wu, R. Identification of quantitative trait loci for altitude adaptation of tree leaf shape with Populus szechuanica in the Qinghai-Tibetan plateau. Front. Plant Sci. 2020, 11, 632. [CrossRef]

44. Rushfort, K. Trees of Britain \& Europe, 1st ed.; HarperCollins Publishers LLC.: New York, NY, USA, 1999; Volume 1, p. 1336.

45. Isebrands, J.G.; Richardson, J. Introduction. In Poplars and Willows, 1st ed.; Isebrands, J.G., Richardson, J., Eds.; CABI: Wallingford, UK, 2014; Volume 1, pp. 1-7.

46. Hörandl, E.; Florineth, F.; Hadacek, F. Weiden in Österreich und Angrenzenden Gebieten, 2nd ed.; University of Agriculture: Vienna, Austria, 2012; p. 164

47. Trybush, S.; Jahodova, Š.; Macalpine, W.; Karp, A. A genetic study of a Salix germplasm resource reveals new insights into relationships among subgenera, sections and species. Bioener. Res. 2008, 1, 67-69. [CrossRef]

48. Tomaszewski, D. The wax layer and its morphological variability in for European Salix species. Flora 2004, 199, 320-326. [CrossRef]

49. Khalili, Z.; Maassoumi, A.A.; Ghahremaninejad, F.; Mirzaie-Nodoushan, H. Foliar anatomy of some Salix species (Salicaceae) in Iran. Iran. J. Bot. 2010, 16, 293-302.

50. Zou, Y.; Li, X.; Yang, G. Sprout regeneration of shrub willows after cuttings. Plants 2020, 9, 1684. [CrossRef]

51. Maciejewska-Rutkowska, I.; Bocianowski, J.; Wrońska-Pilarek, D. Pollen morphology and variability of Polish native species from genus Salix L. PLoS ONE 2021, 16, e0252253. [CrossRef]

52. Fick, S.E.; Hijmans, R.J. WorldClim 2: New $1 \mathrm{~km}$ spatial resolution climate surfaces for global land areas. Int. J. Climatol. 2017, 37, 4302-4315. [CrossRef]

53. Wani, A.A.; Zargar, S.A.; Malik, A.H.; Kashtwari, M.; Nazir, M.; Khuroo, A.A.; Ahmad, F.; Dar, T.A. Assessment of variability in morphological characters of apricot germplasm of Kashmir, India. Sci. Hortic. 2017, 225, 630-637. [CrossRef]

54. WinFolia TM, version PRO 2005b; Regent Instruments Inc.: Quebec, QC, Canada, 2001.

55. Sokal, R.R.; Rohlf, F.J. Biometry: The Principles and Practice of Statistics in Biological Research, 4th ed.; W.H. Freeman and Co.: New York, NY, USA, 2012; p. 937.

56. STATISTICA (Data Analysis Software System), version 13; StatSoft, Inc.: Tulsa, OK, USA, 2018.

57. Douaihy, B.; Sobierajska, K.; Jasinska, A.K.; Boratynska, K.; Ok, T.; Romo, A.; Machon, N.; Didukh, Y.; Dagher-Kharrat, M.B.; Boratynski, A. Morphological versus molecular markers to describe variability in Juniperus excelsa subsp. excelsa (Cupressaceae). AoB Plants 2012, 2012, pls13.

58. Boratynski, A.; Jasinska, A.K.; Marcysiak, K.; Mazur, M.; Romo, A.M.; Boratynska, K.; Sobierajska, K.; Iszkuło, G. Morphological differentiation supports the genetic pattern of the geographic structure of Juniperus thurifera (Cupressaceae). Plant Syst. Evol. 2013, 299, 773-784. [CrossRef]

59. Sobierajska, K.; Boratynska, K.; Jasinska, A.; Dering, M.; Ok, T.; Douaihy, B.; Dagher-Kharrat, M.B.; Romo, A.; Boratynski, A. Effect of the Aegean Sea barrier between Europe and Asia on differentiation in Juniperus drupacea (Cupressaceae). Bot. J. Linn. Soc. 2016, 180, 365-385. [CrossRef]

60. Poljak, I.; Idžojtić, M.; Šapić, I.; Korijan, P.; Vukelić, J. Diversity and structure of Croatian continental and Alpine-Dinaric populations of grey alder (Alnus incana (L.) Moench subsp. incana): Isolation by distance and environment explains phenotypic divergence. Šumarski list 2018, 142, 19-32. [CrossRef]

61. R Core Team. R: A Language and Environment for Statistical Computing; R Foundation for Statistical Computing: Vienna, Austria, 2016; Available online: http:/ / www.R-project.org/ (accessed on 20 December 2021).

62. Koutecký, P. MorphoTools: A set of R functions for morphometric analysis. Plant Syst. Evol. 2015, 301, 1115-1121. [CrossRef]

63. Hijmans, R.J.; Cameron, S.E.; Parra, J.L.; Jones, P.G.; Jarvis, A. Very high resolution interpolated climate surfaces for global land areas. Int. J. Climatol. 2005, 25, 1965-1978. [CrossRef]

64. Mantel, N. The detection of disease clustering and a generalized regression approach. Cancer Res. 1967, 27, 209-220.

65. Manly, B.F.J. Randomization, Bootstrap and Monte Carlo Methods in Biology, 3rd ed.; Chapman \& Hall; CRC, Taylor \& Francis Group: Boca Raton, FL, USA, 2007; p. 480.

66. Smouse, P.E.; Long, J.C.; Sokal, R. Multiple regression and correlation extensions of the Mantel test of matrix correspondence. Syst. Zool. 1986, 35, 627-632. [CrossRef]

67. Rohlf, F.J. Exeter Software (Firm) NTSYS-Pc: Numerical Taxonomy and Multivariate Analysis System; Applied Biostatistics, Inc.: Setauket, NY, USA, 2009.

68. Krüssmann, G. Handbuch der Laubgehölze, 1st ed.; Paul Parey: Berlin, Germany, 1962; pp. 445-446. 
69. Bartha, D. Salix triandra L. In Enzyklopädie der Holzgewächse: Handbuch und Atlas der Dendrologie, 1st ed.; Roloff, A., Weisberger, H., Lang, U.M., Stimm, B., Schütt, P., Eds.; Wiley-VCH: Weinheim, Germany, 2011; Volume 3, p. 11.

70. Calagari, M.; Modirrahmati, A.R.; Asadi, F. Morphological variation in leaf traits of Populus euphratica Oliv. natural populations. Int. J. Agri. Biol. 2006, 8, 754-758.

71. Clair, S.B.; Monson, S.D.; Smith, E.A.; Cahill, D.G.; Calder, W.J. Altered leaf morphology, leaf resource dilution and defense chemistry induction in frost-defoliated aspen (Populus tremuloides). Tree Physiol. 2009, 29, 1259-1268. [CrossRef]

72. Al Afas, N.; Marron, N.; Ceulemans, R. Variability in Populus leaf anatomy and morphology in relation to canopy position, biomass production, and varietal taxon. Ann. For. Sci. 2007, 64, 521-532. [CrossRef]

73. Čortan, D.; Tubić, B.; Šijačić-Nikolić, M.; Borota, D. Variability of black poplar (Populus nigra L.) leaf morphology in Vojvodina, Serbia. Šumarski List 2015, 139, 245-251.

74. Krauze-Michalska, E.; Boratyńska, K. European geography of Alnus incana leaf variation. Plant Biosyst. 2013, 147, 601-610. [CrossRef]

75. Poljak, I.; Idžojtić, M.; Šapić, I.; Vukelić, J.; Zebec, M. Population variability of grey (Alnus incana /L./Moench) and black alder (A glutinosa/L./Gaertn.) in the Mura and Drava region according to the leaf morphology. Šumarski List 2014, 138 , 7-16.

76. Pyakurel, A.; Wang, J.R. Leaf morphological variation among paper birch (Betula papyrifera Marsh.) genotypes across Canada. Open J. Ecol. 2013, 3, 284-295. [CrossRef]

77. Franiel, I.; Więski, K. Leaf features of silver birch (Betula pendula Roth). Variability within and between two populations (uncontaminated vs Pb-contaminated and Zn-contaminated site). Trees 2005, 19, 81-88. [CrossRef]

78. Dancik, B.P.; Barnes, B.V. Leaf variability in yellow birch (Betula alleghaniensis) in relation to environment. Can. J. For. Res. 1975, 5, 149-159. [CrossRef]

79. Halle, F.; Oldeman, R.A.A.; Tomlinson, P.B. Tropical Trees and Forests: An Architectural Analysis, 1st ed.; Springer: Berlin/Heidleberg, Germany, 1978; p. 463.

80. Hovenden, M.J.; Vander Schoor, J.K.; Osanai, Y. Relative humidity has dramatic impacts on leaf morphology but little effect on stomatal index or density in Nothofagus cuninghamii (Nothofagaceae). Aus. J. Bot. 2012, 60, 700-706. [CrossRef]

81. Gong, H.; Gao, J. Soil and climatic drivers of plant SLA (specific leaf area). Glob. Ecol. 2019, 20, e00696. [CrossRef]

82. Ashman, T.-L. The limits on sexual dimorphism in vegetative traits in a gynodioecious plant. Am. Nat. 2005, 166, 5-16. [CrossRef]

83. Barret, S.C.H.; Hough, J. Sexual dimorphism in flowering plants. J. Exp. Bot. 2013, 64, 67-82. [CrossRef]

84. Nicotra, A.B.; Chazdon, R.L.; Montgomery, R.A. Sexes show contrasting patterns of leaf and crown carbon gain in a dioecious rainforest shrub. Am. J. Bot. 2003, 90,347-355. [CrossRef]

85. Li, C.; Xu, G.; Zang, R.; Korpelainen, H.; Berninger, F. Sex-related differences in leaf morphological and physiological responses in Hippophae rhamnoides along an altitudinal gradient. Tree Psysiol. 2007, 27, 399-406. [CrossRef]

86. Slate, M.L.; Rosenstiel, T.N.; Eppley, S.M. Sex-specific morphological and physiological differences in the moss Ceratodon purpureus (Dicranales). Ann. Bot. 2017, 120, 845-854. [CrossRef]

87. Ågren, J.; Danell, K.; Elmqvist, T.; Eriscon, L.; Hjältén, J. Sexual dimorphism and biotic interactions. In Gender and Sexual Dimorphism in Flowering Plants; Geber, M.A., Dawson, T.E., Delph, L.F., Eds.; Springer: Berlin, Germany, 1999; pp. 217-246. [CrossRef]

88. Hultine, K.R.; Grady, K.C.; Wood, T.E.; Shuster, S.M.; Stella, J.C.; Whitham, T.G. Climate change perils for dioecious plant species. Nat. Plants 2016, 2, 16109. [CrossRef] [PubMed]

89. Korgiopoulou, C.; Bresta, P.; Nikolopoulos, D.; Karabourniotis, G. Sex-specific structural and functional leaf traits and sun-shade acclimation in the dioecious tree Pistacia vera (Anacardiaceae). Funct. Plant Biol. 2019, 46, 649-659. [CrossRef] [PubMed]

90. Wheelwright, N.T.; Sinclair, J.P.; Hochwender, C.; Janzen, F.J. Leaf size in three generations of a dioecious tropical tree, Ocotea tenera (Lauraceae): Sexual dimorphism and changes with age. Am. J. Bot. 2012, 99, 1350-1355. [CrossRef] [PubMed]

91. Brus, R.; Idžojtić, M.; Jarni, K. Morphologic variation in northern marginal Juniperus oxycedrus L. subsp. oxycedrus populations in Istria. Plant Biosyst. 2014, 150, 274-284. [CrossRef]

92. Garbarino, M.; Weisberg, P.J.; Bagnara, L.; Urbinati, C. Sex-related spatial segregation along environmental gradients in the dioecious conifer, Taxus baccata. For. Ecol. Manag. 2015, 358, 122-129. [CrossRef]

93. Gouker, F.G.; Carlson, C.H.; Zou, J.; Evans, L.; Crowell, C.R.; Smart, C.D.; DiFazio, S.P.; Smart, L.B. Sexual dimorphism in the dioecious willow Salix purpurea. Am. J. Bot. 2021, 108, 1374-1387. [CrossRef]

94. Midgley, J.J. Causes of secondary sexual differences in plants-Evidence from extreme leaf dimorphism in Leucadendron (Proteaceae). S. Afr. J. Bot. 2010, 76, 588-592. [CrossRef]

95. Stefanović, M.; Nikolić, B.; Matić, R.; Popović, Z.; Vidaković, V.; Bojović, S. Exploration of sexual dimorphism of Taxus baccata L. needles in natural populations. Trees 2017, 31, 1697-1710. [CrossRef]

96. Sanderson, B.J.; Wang, L.; Tiffin, P.; Wu, Z.; Olson, M.S. Sex-biased gene expression in flowers, but not leaves, reveals secondary sexual dimorphism in Populus balsamifera. New Phytol. 2019, 221, 527-539. [CrossRef]

97. Robinson, K.M.; Delhomme, N.; Mähler, N.; Schiffthaler, B.; Önskog, J.; Albrectsen, B.R.; Ingvarsson, P.K.; Hvidsten, T.R.; Jansson, S.; Street, N.R. Populus tremula (European aspen) shows no evidence of sexual dimorphism. BMC Plant Biol. 2014, 14, 276. [CrossRef]

98. Du, Q.; Xu, B.; Gong, C.; Yang, X.; Pan, W.; Tian, J.; Li, B.; Zhang, D. Variation in growth, leaf, and wood property traits of Chinese white poplar (Populus tomentosa), a major industrial tree species in Northern China. Can. J. For. Res. 2014, 44, 326-339. [CrossRef] 
99. McKown, A.D.; Klápště, J.; Guy, R.D.; Soolanayakanahally, R.Y.; La Mantia, J.; Porth, I.; Skyba, O.; Unda, F.; Douglas, C.J.; El-Kassaby, Y.A.; et al. Sexual homomorphism in dioecious trees: Extensive tests fail to detect sexual dimorphism in Populus. Sci. Rep. 2017, 7, 1831. [CrossRef] [PubMed]

100. Ueno, N.; Suyama, Y.; Seiwa, K. What makes the sex ratio female-biased in the dioecious tree Salix sachalinensis? J. Ecol. 2007, 95, 951-959. [CrossRef]

101. Dudley, L.S.; Galen, C. Satge-dependent patterns of drought tolerance and gas exchange vary between sexes in the alpine willow, Salix glauca. Oecologia 2007, 153, 1-9. [CrossRef]

102. Chavarriá-Soley, G.; Contreras, J.; Raventoś, H. Chapter 6-Founder variations in isolated populations. In Translational and Applied Genomics, Genome Plasticity in Health and Disease; Forero, D.A., Patrinos, G.P., Eds.; Academic Press: Cambridge, MA, USA, 2020; pp. 77-91. [CrossRef]

103. Royer, D.L.; McElwain, J.C.; Adams, J.M.; Wilf, P. Sensitivity of leaf size and shape to climate within Acer rubrum and Quercus kelloggii. New Phytol. 2008, 179, 808-817. [CrossRef] [PubMed]

104. Li, X.; Li, Y.; Zhang, Z.; Li, X. Influences of environmental factors on leaf morphology of Chinese jujubes. PLoS ONE 2015, 10, e0127825. [CrossRef]

105. Radersma, R.; Noble, D.W.A.; Uller, T. Plasticity leaves a phenotypic signature during local adaptation. Evol. Lett. 2020, 4, 360-370. [CrossRef]

106. Meunier, C.; Boersma, M.; El-Sabaawi, R.; Halvorson, H.M.; Herstoff, E.M.; Van de Waal, D.B.; Vogt, R.J.; Litchman, E. From elements to function: Toward unifying ecological stoichiometry and trait-based ecology. Front. Environ. Sci. 2017, 5, 18. [CrossRef]

107. Aerts, R.; Chapin, F.S. The mineral nutrition of wild plants revisited: A reevaluation of processes and patterns. Adv. Ecol. Res. 2000, 30, 1-67. [CrossRef]

108. Chown, S.L.; Gaston, K.J.; Robinson, D. Macrophysiology: Large-scale patterns in physiological traits and their ecological implications. Funct. Ecol. 2004, 18, 159-167. [CrossRef]

109. Wright, I.J.; Reich, P.B.; Westboy, M.; Ackerly, D.D.; Baruch, Z.; Bongers, F.; Cavender-Bares, J.; Chapin, T.; Cornelissen, J.H.C.; Diemer, M.; et al. The worldwide leaf economics spectrum. Nature 2004, 428, 821-827. [CrossRef] [PubMed]

110. Liu, M.; Wang, Z.; Li, S.; Lü, X.; Wang, X.; Han, X. Changes in specifc leaf area of dominant plants in temperate grasslands along a 2500-km transect in northern China. Sci. Rep. 2017, 7, 10780. [CrossRef] [PubMed]

111. Wilson, P.J.; Thompson, K.; Hodgson, J.G. Specific leaf area and leaf dry matter content as alternative predictors of plant strategies. New Phytol. 1999, 143, 155-162. [CrossRef]

112. Dwyer, J.M.; Hobbs, R.J.; Mayfield, M.M. Specific leaf area responses to environmental gradients through space and time. Ecology 2014, 95, 399-410. [CrossRef]

113. Wright, S. Isolation by distance. Genetics 1943, 28, 114-138. [CrossRef]

114. Wang, I.J.; Bradburd, G.S. Isolation by environment. Mol. Ecol. 2014, 23, 5649-5663. [CrossRef]

115. Sexton, J.P.; Hangartner, S.B.; Hoffmann, A. Genetic isolation by environment or distance: Which pattern of gene flow is most common? Evolution 2013, 68, 1-15. [CrossRef]

116. Holt, R.D.; Gomulkiewicz, R. How does immigration influence local adaptation? A re-examination of a familiar paradigm. Am. Nat. 1997, 149, 563-572. [CrossRef]

117. Sexton, J.P.; Strauss, S.Y.; Rice, K.J. Gene flow increases fitness at the warm edge of a species' range. Proc. Natl. Acad. Sci. USA 2011, 108, 11704-11709. [CrossRef]

118. Dewoody, J.; Trewin, H.; Taylor, G. Genetic and morphological differentiation in Populus nigra L.: Isolation by colonization or isolation by adaptation? Mol. Ecol. 2015, 24, 2641-2655. [CrossRef] [PubMed]

119. Riordan, E.C.; Gugger, P.F.; Ortego, J.; Smith, C.; Gaddis, K.; Thompson, P.; Sork, V.L. Association of genetic and phenotypic variability with geography and climate in three southern California oaks. Am. J. Bot. 2016, 103, 73-85. [CrossRef] [PubMed]

120. Buzatti, R.S.O.; Pfeilsticker, T.R.; Muniz, A.C.; Ellis, V.A.; Souza, R.P.; Lemos-Filho, J.P.; Lovato, M.B. Disentangling the environmental factors that shape genetic and phenotypic leaf trait variation in the tree Qualea grandiflora across the Brazilian savanna. Front. Plant Sci. 2019, 10, 1580. [CrossRef] [PubMed]

121. Vidaković, A.; Liber, Z.; Šatović, Z.; Idžojtić, M.; Volenec, I.; Zegnal, I.; Pintar, V.; Radunić, M.; Poljak, I. Phenotypic diversity of almond-leaved pear (Pyrus spinosa Forssk.) along Eastern Adriatic coast. Forests 2021, 12, 1630. [CrossRef]

122. Gao, J.; Liu, Z.-L.; Zhao, W.; Tomlinson, K.W.; Xia, S.-W.; Zeng, Q.-Y.; Wang, X.-R.; Chen, J. Combined genotype and phenotype analyses reveal patterns of genomic adaptation to local environments in the subtropical oak Quercus acutissima. J. Syst. Evol. 2021, 59, 541-556. [CrossRef] 